Original Research Article

Good governance, political experiences, and public support for mandatory sentencing: Evidence from a progressive US state

\title{
Jody Sundt
}

(School of Public and Environmental Affairs) Indiana University-Purdue University Indianapolis, USA

\section{Kathryn Schwaeble}

(School of Public and International Affairs) North Carolina State University, Raleigh, USA

\section{Cullen C. Merritt}

(School of Public and Environmental Affair) Indiana University-Purdue University Indianapolis, USA

Authors' Copy

Forthcoming at Punishment and Society

Accepted November 19, 2017

Corresponding author:

Jody Sundt, School of Public and Environmental Affairs, 801 W. Michigan St., Indianapolis, IN 46202

Email: jsundt@iupui.edu 


\title{
Good governance, political experiences, and public support for mandatory sentencing: Evidence from a progressive US state
}

\begin{abstract}
A shift in public mood and declining incarceration rates in the US signal a potential change in the politics of punishment. This research considers whether the public continues to support mandatory sentencing. The study expands upon existing knowledge by testing theoretical predictions about how instrumentalism, political beliefs and political participation affect public support for mandatory sentences. Drawing on a state-wide survey of 1,569 adults from Oregon the study found that belief in the effectiveness of prosecutors, judges, and prisons significantly influenced support for mandatory sentencing. Although $67 \%$ of those surveyed favored judicial discretion, a firm belief that "prisons work" may limit efforts to reduce incarceration and roll back mandatory sentences.
\end{abstract}

\section{Keywords}

public opinion; mandatory sentencing; trust in government; prosecutors; judges 


\section{Good governance, political experiences, and public support for mandatory sentencing: Evidence from a progressive US state}

Beginning in 2010, the United States prison population declined for the first time in more than 30 years. Five years later, it stood at 2005 levels (Carson and Anderson, 2016). The public mood in the US has also moderated. Citizens are willing to downsize prisons (Sundt, Cullen, Jonson, and Thielo, 2015) as long as it does not come at the cost of public safety (Pew Charitable Trusts, 2012), and even traditionally “tough” US states like Texas are pursuing reforms with broad citizen support for treatment and prevention (Thielo, Cullen, Cohen, and Chouhy, 2016). Optimists and reform advocates point to these developments as signs of a social movement toward greater tolerance.

There are also signs, however, that declines in the US incarceration rate and the political will for reform are tenuous. Most of the decline in the US prison population may be attributed to California and the federal prison system, while many states continue to increase their rates of incarceration (Carson and Anderson, 2016). In California, reforms were driven by a unique confluence of political, legal, and economic conditions (Schlanger, 2013). Declines in the federal prison population occurred under the Obama Administration, which made criminal justice reform a priority. Now, the Trump Administration has signalled a return to "law and order" and a rise in the homicide rate in several cities are again raising alarms about the threat of violent crime (Epstein, 2017). To borrow a phrase, it appears that reports of the death of punitive policy in the US are exaggerated.

Nevertheless, it is clear that the politics of punishment are changing. If the prison build-up was the result of public demand for more punishment (Enns, 2014), will changes in public mood ultimately result in broader, sustained reductions in incarceration and a rollback of “tough” sentencing laws? This question draws our 
attention to the way punishment is tied to political life. Cutting through the complexity about the causes of mass incarceration in the US, Travis, Western, and Redburn (2014) explain that growth in imprisonment resulted from a choice to pass laws increasing sentence lengths for a broader range of crimes.

By locating the source of mass incarceration within political processes that affect sentencing and local decision making, scholars focus our attention more explicitly on the relationship between governance and punishment. For example, Simon (2007) emphasizes how crime became a tool for governing, and crime control emerged as a tangible political good provided to fearful constituents who lost confidence in the ability of traditional institutions and professionals to address public safety. Barker (2009) also locates the growth in incarceration in political life and argues that the ways individuals participate in democratic processes affects how states use punishment and maintain legitimacy with their citizens. Pfaff (2017) shows how local political incentives and disincentives encourage prosecutors and other local criminal justice officials to overreact to increases in crime but little reason to change policy when crime falls.

The current study considers whether the public continues to support mandatory sentencing in the context of these broader social and political changes. The study expands upon existing research by testing theoretical predictions about how instrumentalism, political beliefs and political participation affect public support for tough penalties. We consider these issues by surveying residents of Oregon. Although Oregon is a progressive state politically it also has a strong affinity for mandatory sentencing and the Oregon prison population continues to grow. These conditions provide an intriguing context to examine questions about political beliefs and sentencing policies. 


\section{Public attitudes and the politics of punitiveness}

Public opinion is central to debates about the role that politics play in shaping United States punishment policies. While we know that citizens’ attitudes are important, the relationship between public opinion and public policy is complicated (Frost, 2010; Unnever and Cullen, 2010). It is unclear, for example, whether public opinion drives sentencing policy or whether politicians motivate support for policies with punitive rhetoric (Beckett and Sasson, 2000; Roberts and Hough, 2005; Tonry, 2004). Gaubatz (1995) observes, "the movement in public opinion largely preceded the changes in policy” during the get-tough era (p. 9). Nicholson-Crotty and colleagues’ (2009) findings are consistent with Gaubatz. “[A] more punitive public opinion results directly in more punishment. In [the] case [of Federal policy], we know that demands for action from the government result in specific action” (p. 652). More recently, Frost (2010) argues the relationship is reciprocal, "with public opinion playing an important role in the development of public policy and political posturing affecting public opinion” (p. 157).

The association between public opinion and punitive policies may also be examined through the lens of incarceration rates in the United States. For example, Enns (2014) finds that punitiveness is a "fundamental determinant of the incarceration rate. In fact, if instead of becoming more punitive, the public's support for being tough on crime had remained constant since the mid-1970s... there would be about $20 \%$ fewer people incarcerated today” (p. 869). Enns’ analytical strategy is noteworthy because incarceration rates shed light on the effects of punitive policies, rather than the mere existence of policies. Furthermore, the findings provide a sense of how criminal justice officials respond to public opinion in administering policy.

Several frameworks attempt to explain why the public supports getting tough on 
crime. Of particular interest here are two ideas. First, individuals may endorse punitive responses to crime because they believe that it is good policy—it protects the public, is efficient, and serves justice. This view is consistent with a rational-goal model of criminal justice (Feeley, 1973). According to this perspective, punitive policies "work" and criminal justice professionals are considered competent professionals who can effectively respond to crime. Second, punitive policies may be influenced by political experiences, structures, and beliefs. This view posits that punitiveness results from a lack of trust in government institutions and a sense that criminal justice professionals are not responsive to public safety needs. The escalating crime and distrust model is similar to the idea of a moral panic in regards to the issue of crime, which explains the existence of a punitive trend even in the absence of a rise in crime rates. In both of these views, perceived (if not actual) increases in crime and fear of crime are thought to increase punitiveness. The two perspectives differ, however, in predictions about how trust in government and confidence in criminal justice professionals will affect punitiveness.

Public support for mandatory sentencing is an especially good exemplar of these theoretical models due to the strong association between mandatory punishments and "tough" crime control and the way that mandatory sentences substitute legislative and prosecutorial authority for judicial authority. Simon (2007) observes that prosecutors have replaced judges as the most trusted agent of the courts. As the power of the prosecutor rose, he argues, judges began to be perceived as betrayers of the common good, namely too soft on crime. Within mandatory sentences we see strains of instrumental crime control and shifting ideas about how government should exercise coercive authority. By mandating punishment, mandatory sentences may also reflect a 
lack of trust in criminal justice professionals to exercise discretion in the public interest (Zimring and Johnson, 2006).

Mandatory sentences have garnered mixed support in public opinion polls. In a review of the research, Roberts (2003) concludes that the public is "deeply divided" regarding mandatory sentencing policies (p. 483). A comparison of opinions in the mid-1990s to the early 2000s also demonstrates the fluidity of public opinion on mandatory sentencing. Between1995 and 2002, the number of respondents who said mandatory sentences “are a good idea” dropped from 55\% to 45\% (Peter D. Hart Research Associates, Inc., 2002). A1999 poll linking policy preference to voting intention revealed that more than half of the sample "would be more likely to vote for a politician who advocated increasing judicial discretion — the antithesis to mandatory sentencing” (Roberts et al., 2007, p. 77). Finally, a 2014 poll found that $77 \%$ of Americans favored eliminating mandatory minimum prison sentences for nonviolent offenders (Ekins, 2014). Together these results suggest that public support for mandatory sentences is “mushy” and dynamic_-perhaps sensitive to offender type, question wording, and social context.

\section{Punitiveness as Effective Crime Control}

If longer sentences reflect the "will of the people" and government policy is responsive to citizen demands, what motivates the public's desire for more punishment? The answer to this question may be simplified into two categories-instrumental and expressive motives. Thus, punitiveness may be viewed as utilitarian, leading to a particular public good, or as affective, reflecting various emotions and expressive desires. Although scholars hypothesize that the increased punitiveness of the last several decades reflects broad cultural and social shifts more consistent with affective 
motives (Garland, 2001; Simon, 2007; Tonry, 2004), there is also evidence of utilitarianism among members of the public.

For example, Nicholson-Crotty et al. (2009) found that the crime rate mediated the relationship between policies and public support for punishment suggesting that the public responds to objective changes in public safety with a desire for more punitive policy. Public opinion about sex crimes also appears to be influenced by utilitarian concerns. Pickett et al. (2013) found that beliefs that sex crime is on the rise and that sex offenders are unreformable predicted support for tougher sex crime laws. Useem, Liedka and Piehl (2003) found little support for the assertion that punitiveness is caused by social disruptions like job loss and life dissatisfaction. They conclude the prison buildup was primarily due to public concern about crime and belief that incarceration could address that concern.

Other observers argue that the distinction between instrumental and expressive motivations for punishment is blurred. Hudson (2001) reminds us, for example, that rational policies and harsh policies have simultaneously been enacted, and the balance between managerial rationality and populist punitiveness can shift. Rational policies, Hudson argues, indicate an acceptance of high crime rates as normal but manageable with a focus on public protection rather than just deserts. More recently, Carvalho and Chamberlen (2017) argue that punishment pleases because it appeals to a desire for utility. “[P]eople may... want to believe punishment has utility because of the way it makes them feel” (p. 4).

Belief in the utilitarian appeal of prisons may be especially relevant to understanding why incarceration rates have increased over the last several decades. A comprehensive review of research conducted in 1980s and 1990s found that the public had a strong preference for punishing a wide range of crimes with imprisonment 
(Cullen et al. 2000). Although the public appears skeptical about the ability of prisons to change individuals, they nevertheless see value in the ability of prisons to incapacitate offenders, particularly those who are dangerous and violent. Even in the context of waning public support for harsh punishments and a willingness to consider alternatives to long prison sentences, $84 \%$ of the public favored sending fewer low-risk, nonviolent offenders to prison in order to keep violent criminals in prison for their full sentences (Pew Charitable Trusts, 2012).

\section{Punitiveness and Political Experiences}

A number of political experiences and attitudes have gained theoretical interest as attention has shifted to understanding the prison build-up as a policy choice. Three concepts are of particular interest: trust in government, political participation and responsiveness, and political ideology. Trust in government can influence the public's willingness to support government policies and a "trust deficit" in Western countries may lead to policies that align with common sense, rather than evidence (Baker and Roberts, 2013, p. 126). A lack of trust may also explain why highly punitive policies have been widely implemented and accepted by the public (Baker and Roberts, 2013; Hudson, 2001). For example, Zimring et al. (2001) found that Californians who were the most distrustful of government were the most likely to support a "three strikes" law. The level of confidence in the courts is consistently lower than the levels of confidence in the entire criminal justice system, the police, or prisons (Freiberg and Gelb, 2008), and an "acute crisis of confidence in elite expertise" is said to be evident in the US (Green, 2009, p. 528). Confidence in court actors may also help to explain beliefs about judicial discretion. "The statistics show that the overwhelming proportion of Americans express the view that sentences are too lenient (Roberts et al., 2003, p. 27).

Simon (2007) frames governing through crime as establishing social control in 
the absence of trust. He views punitive policy preferences as a combination of beliefs that crime is escalating and professionals cannot handle this rise effectively. Barker (2007) proposes a more nuanced view, theorizing that social trust is one factor impacting whether pragmatic or punitive views dominate. Overall, she posits that a context with a high degree of democratization and intense social polarization is more likely to result in crime victim demands for vengeance, while a context with intensive civic engagement and well-developed social trust and norms of reciprocity are more likely to result in pragmatic policies (Barker, 2007).

The degree to which government is responsive to citizens’ preferences may also influence the relationship between policy, civic participation, and trust (Teorell, 2006). For example, if citizens do not believe that criminal justice officials are responsive to their concerns about crime this may increase support for mandatory sanctions, which appear to require certain action. Similarly, participation may be related to beliefs about political trust and responsiveness. Belief that government is trustworthy and responsive may also affect a willingness to participate in civic action or participation may increase trust when citizens believe that their engagement has influenced policy (Teorell, 2006).

Finally, political ideology appears to be a central factor in explaining public opinion about punishment (Frost, 2010). Specifically, liberals report less support for mandatory minimums (Flanagan, Brennan, and Cohen, 1991), which may be explained in part by the finding that Democrats are more supportive of judicial discretion (Gerber and Engelhardt-Greer, 1996). Similarly, liberals are said to be less punitive generally, while Americans who identify as conservative are more punitive (Frost, 2010).

Simon links ideas about governance to citizens’ fear of crime. By framing all citizens as actual and potential victims, lawmakers create a "constantly renewed rationale for legislative action” (2007, p. 77). Combined with a lack of institutional 
trust in the courts, this narrative fuels a culture of fear and creates a perpetual cycle of punitive policies. Barker (2009) views penal sanctions as the product of collective action. How people react to fear and the threat of crime is moderated by government structures that encourage or discourage civic engagement, trust, and reciprocity.

\section{Research Strategy}

We test the effect of three models predicted to influence support for mandatory sentencing among residents of Oregon. Oregon voters have passed several mandatory sentencing laws covering a wide range of behaviour by direct voter initiative. The most infamous of these initiatives, Measure 11, was enacted in 1994 with close to $67 \%$ of voters supporting the ballot initiative. The law required that individuals convicted of 1 of 19 crimes serve a mandatory minimum prison sentence that ranged from 70 to 300 months. The law also prohibited "earned time” and mandated automatic transfer of juveniles charged with a "Measure 11" crime to adult court (Merritt, Fain, and Turner, 2006). Attempts to repeal Measure 11 by legislative action or ballot initiative have failed (Merritt et al., 2006). In addition to Measure 11, two other major mandatory sentencing laws were passed by direct voter initiative in 2008 and 2010, the first increasing minimum sentences for repeat property and drug offenders and the second for repeat sex offenses and drunk driving.

Although Oregon ranks near the median nationally in punitiveness and imprisonment rates, the punishment rate — the ratio of inmates to crime-increased by 214\% between 1983 and 2013 (Pew Charitable Trusts, 2016). In addition, Oregon’s prison population and rate of incarceration continue to grow (Carson and Anderson, 2016). Measure 11 is a one of the primary drivers of the increase in Oregon's incarceration rate. Measure 11 increased the rate of incarceration in the state and the length of sentences across a range of offenses including those not covered by the law 
(Merritt, et al. 2006). Examining the source of support for mandatory sentencing among Oregon residents is an opportunity to understand why some US states continue to pursue policies that increase reliance on incarceration.

\section{Methods}

\section{Sample and Data Collection}

In the summer of 2010, survey data were gathered from a random sample of 1,569

Oregon adults with a 15-minute telephone survey administered by the Portland State University Survey Research Laboratory. Surveys were conducted in English and Spanish. The sample was stratified by region to more accurately represent the geographical and population areas of the state. In addition, African American and Hispanic residents were oversampled to obtain more reliable results from members of these racial and ethnic groups.

Based on formula 3 of American Association of Public Opinion Research (2008) standards, the response rate for the general sample was $12 \%$, which is consistent with response rates obtained in recent national telephone polls (Keeter, Hatley, Kennedy, and Lau, 2017). Although response rates have declined in recent years, this has not necessarily affected the representativeness of phone surveys. This is because response rates are not a good indicator of non-response bias, which tends to be question specific (Peytchev, 2013). Sampling error and comparison of sample characteristics with population parameters provide a better indicator of representativeness than response rates alone. In the current study, the error attributed to sampling at the $95 \%$ level of confidence was plus or minus 2.47 percentage points. Women were overrepresented in the study due to their higher participation rates. The descriptive results reported below are therefore weighted to accurately reflect the proportion of women and racial minorities in the population of Oregon. 


\section{Measures}

Support for mandatory sentencing

Global support for mandatory sentencing was measured with an item used in previous public opinion polls (e.g., Princeton Research Associates, 2006). Respondents were instructed: “Oregon currently requires a prison sentence of a specific length of time for all who are convicted of certain crimes.” Next, participants were asked, “In general, do you think mandatory sentences are a good idea, or do you think that judges should have more say in deciding sentences?” This dichotomous item provides a measure of respondents' general attitudes toward mandatory sentences and judicial discretion ( 1 = mandatory sentences are a good idea; 0 = judges should have more say). Care was taken to avoid evoking opinions about existing or pending ${ }^{1}$ mandatory sentences laws or about specific types of offenders to obtain an indicator of global attitudes. Less than $2 \%$ of respondents volunteered that they "did not know."

Perceived efficacy of criminal justice institutions

Prior research suggests that confidence in judges and prosecutors may be important determinants of support for mandatory sentences. Confidence in the efficacy of judges and prosecutors was measured by asking participants to share their "opinion on how well different groups in Oregon are doing addressing crime and public safety.” Groups included “judges” and "prosecutors and district attorneys,” as well as other criminal justice actors such as law enforcement and correctional officers. Representatives of the criminal justice system were presented in random order on the survey and respondents were asked to indicate whether each group was doing a "poor job,” “fair job,” "good job,” or “excellent job.” Twelve percent of respondents volunteered that they did not know how well prosecutors performed their jobs and 10\% said they did not have an opinion about the efficacy of judges. Non-response was unrelated to attitudes about 
mandatory sentencing. These participants were excluded from further analysis. The items were treated as continuous variables with higher scores indicating a higher level of confidence in the work of prosecutors and judges.

As discussed above, preference for mandatory sentencing may also be based on certain beliefs about prisons. Two ideas are explored here-belief that the purpose of prison is to protect the public and belief that the purpose of prison is to punish offenders. Thus we distinguish between the perceived efficacy of prisons as a tool for promoting public safety and support for incarceration based on more expressive, punitive desires. These concepts were measured by asking respondents to report what they believe should be the "main emphasis in most prisons.” Response options included "punishing the individual convicted of a crime," "trying to rehabilitate the individual so that they might return to the community as a productive citizen,” and "protecting society from future crimes they might commit.” Dichotomous variables were created with support for rehabilitation as the excluded group.

\section{Political beliefs and experiences}

As discussed above, a preference for mandatory sentencing is expected to be higher when citizens do not believe that government is trustworthy or responsive to their interests and when they do not participate in political processes. The American National Elections Studies' (nd) political trust index was used here as a global indicator of political trust in government. The political trust index is the most widely accepted measure of satisfaction with political life and assesses whether government is performing as respondents expect (Craig, Niemi, and Silver, 1990). Respondents were asked to report their level of disagreement or agreement with statements such as "I trust the government in Washington, DC to do what is right” and “The government is run by 
well meaning people.” The latent concept “political trust” was measured by summing the factor weighted standardized variables (alpha reliability $=.78$ ).

In addition, a modified version of the ANES external political efficacy index was used to measure belief in the responsiveness of government to citizen demands (Craig et al., 1990). The external political efficacy index consisted of three items including "Public officials don't care much about what people like me think" and "I feel like my vote matters” (alpha $=.71)$.

Political participation was measured by asking respondents whether they voted in the last presidential election $(1=$ yes; $0=$ no), which was the most recent election at the time the survey was administered. As a point of reference participants were reminded, “This was the 2008 election between Barack Obama and John McCain.” Political ideology was measured by asking individuals to self-identify as liberal or conservative on a 7-point scale, with 1 representing “extremely liberal” and 7 representing “extremely conservative.” Victimization, perceived risk, and fear of crime Advocates of mandatory sentences often invoke the needs of crime victims as a basis for limiting judicial discretion. Scholars also hypothesize that the fear of crime and perceived risk of victimization are sources of support for punitive policies.

Victimization was measured by asking respondents whether they had experienced any of 9 specific property and personal crimes in the previous year. We explored various coding strategies including total victimization experiences, personal victimization, property victimization, or any victimization within the previous year. There were no significant differences in the correlations between the various measures and the dependent variable. Thus, we retained the most parsimonious and inclusive measure, victimization within the last year $(1=$ yes; $0=$ no). To measure perceived risk of crime, 
participants were asked if they believed that crime in the state of Oregon had “increased,” “decreased,” or "stayed about the same” in the past year. Finally, respondents were asked to report how often they felt safe in "their community" to measure fear of crime. Possible responses included "always feel safe," "almost always feel safe," "sometimes feel safe,” “almost never feel safe,” and "never feel safe.”

\section{Control variables}

Age, income, gender ( $1=$ female; $0=$ male $)$, and race $(1=$ African American; $0=$ other race) were included as control variables.

\section{Results}

Attitudes about Sentencing, Judges, and Prosecutors

Although Oregon citizens have a history of supporting mandatory sentences at the ballot box, $64 \%$ of survey respondents thought "judges should have more say” in determining criminal sentences, whereas 37\% said “mandatory sentences are a good idea.” This result can be compared to polls of US adults conducted in 1995, 2001, and 2006. The percentage of residents endorsing mandatory sentences as a "good idea” has markedly declined over this time period. In 1995, 55\% of the public said mandatory sentences were a "good idea" (Flanagan and Longmire, 1995). By 2001, however, only 38\% of US residents thought the policy was a "good idea” (Peter Hart and Associates, 2002). Finally, a 2006 poll found that $36 \%$ of the public thought mandatory sentences were a “good idea” (Princeton Survey Research Associates, 2006). The 2006 result is within the margin of error found in the current study, suggesting that general support for mandatory sentences may have plateaued around 36\%.

Oregonians reported moderate levels of confidence in the work of judges and prosecutors (See Table 1). Although few participants said that judges or prosecutors were doing an “excellent” job (4.7\% or less), a plurality thought that judges (46\%) and prosecutors (46\%) were doing a "good job” of addressing crime and public safety. 
However, a level of skepticism about judges and prosecutors was reported by approximately half of the sample, which viewed the work of judges and prosecutors as “fair” (37\% to 39\%) or “poor” (12.5\% to $11 \%)$.

[Table 1 About Here]

\section{Sources of Support for Mandatory Sentencing}

The sources of support for mandatory sentences were estimated in three logistic regression models. The first model examined the set of variables that can be summarized as perceptions about the efficacy and utility of specific criminal justice actors and prisons. The second model examined the effect of general political beliefs and political participation. Finally, a full model including all of the variables of interest was estimated. The results of the analyses are reported in Table 2.

\section{[Table 2 About Here]}

Beliefs about the efficacy of criminal justice institutions exert an important influence on support for mandatory sentences in the first model tested. Specifically, confidence in prosecutors $(\mathrm{B}=.32, \mathrm{p} \leq .05)$ significantly increased the odds of favouring mandatory sentences. Controlling for other variables in the model, a unit increase in prosecutor efficacy was associated with a 37\% increase in the odds of supporting mandatory sentences. Conversely, a unit increase in perceived judicial efficacy was associated with a $22 \%$ decrease in support for mandatory sentences (B = $.25, \mathrm{p} \leq .05)$.

Attitudes about prisons had the strongest influence on support for mandatory sentences among Oregon residents in the first model. Other things being equal, belief that prisons protect the public increased the odds of favoring mandatory sentences by 152\%. Controlling for other influences, belief that prisons should be used for punishment increased the odds of supporting mandatory sentencing by $13 \%$ ( $\mathrm{B}=.79$, $\mathrm{p}$ 
$\leq .05)$. Finally, belief that crime rose in the previous year increased the odds of supporting mandatory sentences by $34 \%(B=.30, p \leq .05)$.

The second model testing the effect of political experiences was less successful in accounting for sentencing preferences, although the overall model was statistically significant $\left(\chi^{2}=77.2, \mathrm{p} \leq .05\right)$. Only self-reported political ideology and perceived risk of crime predicted support for mandatory sentences. A unit increase in conservatism was associated with a $26 \%$ increase in the odds of support for mandatory sentences $(B=$ $.23, \mathrm{p} \leq .05)$. An increase in perceived risk of crime increased the odds of supporting mandatory sentences by 34\%. Political trust, political efficacy, and political participation were unrelated to support for mandatory sentencing after other variables in the model were controlled.

In the full model, attitudes about the efficacy of prosecutors, judges, prisons, and conservatism remained robust determinants of sentencing preferences. Perceived risk of crime, however, was no longer statistically significant. The strength of the relationship between beliefs about prisons and mandatory sentences changed somewhat once conservatism was included in the analysis. In the full model, the effect of "prisons should punish" became somewhat stronger whereas the effect of "prisons protect" became somewhat weaker. Still, belief that the main purpose of prisons is protection had the largest effect on the odds of supporting mandatory sentencing in the full model.

\section{Discussion}

If criminal justice policies are a function of political decision making, it appears that Oregonians support mandatory sentencing primarily because they believe it is good policy. Those who endorse mandatory sentences are more likely to have confidence in the efficacy of prosecutors, but not judges, and to believe that prisons protect the public. This interpretation is well captured in a 2013 Willamette Week headline that proclaimed 
“The Hard Truth About Oregon Prisons: They Work.” This feature story ran on the paper's front page and rejected the recommendations of the bipartisan Governor's Commission on Public Safety that proposed policies to reduce the use of incarceration (Jaquiss, 2013). The article focused on Oregon's low recidivism rate, the role that prisons play in removing violent offenders from society, and prosecutors’ strong advocacy in maintaining public safety.

The politics of punishment in Oregon illustrate the limits of reform efforts that seek to reduce reliance on incarceration. Rather than leading on criminal justice reform as might be expected from a state that enjoys low rates of crime (FBI 2015), high levels of civic engagement, and a progressive reputation (Gray and Hanson, 2004), efforts to change sentencing in the state have largely failed and the Oregon prison population continues to increase (Carson and Anderson, 2016). The results obtained here indicate that the tenacity of "tough" policies may be explained in part by confidence in local decision makers and beliefs about prisons rather than broad feelings of trust in government and political efficacy. ${ }^{2}$

This raises an interesting question about the role that knowledge plays in shaping public opinion about policy. Specifically, how knowledgeable is the public about mandatory sentences or the efficacy of prisons, prosecutors, and judges? One way to gauge knowledge is to consider voter turnout and “drop-off," which occurs when voters fill out the "top" of a ballot but do not vote for “down” ballot candidates like judges and district attorneys. Voter engagement in campaigns for judges and prosecutors tends to be low in part because these are often uncontested races. A report by the ACLU of Oregon (2016) found that when elections were competitive in district attorney races, voter drop-off declined from $40 \%$ in uncontested races to $12 \%$ in contested races. Voter knowledge of mandatory sentencing is probably high in Oregon, 
whose citizens have directly voted for numerous measures that expand or attempt to repeal such laws. For example, 85\% of registered Oregonians voted on Measures 57 and 61 in 2008 (Ballotpedia, nd) and millions of dollars have been spent on signature drives and political campaigns for various mandatory sentencing ballot measures. Nevertheless, it is safe to say that knowledge of judges and prosecutors (and criminal justice policy more generally) is probably low. The lack of accurate knowledge among the public about crime and criminal justice is well established (Cullen et al., 2000).

If we assume that citizens' knowledge of these issues is low-or worse, misinformed — it remains unclear what effect accurate knowledge may have on attitudes about crime policy. The NCSC sentencing attitudes survey (Princeton Survey Research Associates, 2006) found, for example, that awareness of mandatory sentencing laws had little influence on attitudes about the use of mandatory sentences in general or for specific types of crime. This finding is consistent with experimental research that finds that people are willing to update their factual beliefs (e.g., that crime did not increase in 2016) but that they interpret facts in a way that remains consistent with their belief systems (Nyhan, Porter, Reifler, and Wood, 2017).

To complicate matters, while we found that utilitarian beliefs about the efficacy of criminal justice institutions were important influences on support for mandatory sentencing, concerns about crime were not. Specifically, we found limited support for the idea that perceived risk of crime increases demand for punishment and no support for the idea that fear of crime or victimization were associated with a preference for mandatory sentences. After other theoretically important concepts were included in the analysis, those who were fearful, believed that crime was rising, or were victims of crime were no more or less likely to support mandatory sentences than participants who were less concerned about and directly affected by crime. 
The disconnection between utilitarian beliefs and concerns about crime appear to be related to political ideology. The results indicate that perceptions about the risk of crime mediate the relationship between political beliefs and attitudes about the purpose of prisons. Political beliefs also appear to have a direct and indirect effect on support for punishment through relationships to perceived risk and beliefs about prison. Thus, conservatives were (1) more likely to believe that crime is increasing compared to more moderate or liberal respondents, (2) more likely to believe that prisons should protect the public and punish, and (3) more likely to endorse mandatory punishment.

The finding that victimization had no effect on support for mandatory sentences is also noteworthy given the centrality of victim's rights to the politics of mandatory sentencing. The success of several ballot initiatives in Oregon expanding the use of mandatory sentencing may be attributed to the effectiveness of Crime Victims United, an influential interest group that has effectively campaigned to pass citizen initiatives increasing sentence lengths and protecting mandatory sentences from repeal or modification (Merritt et al., 2006). Thus, the "valorization of victimization” (Simon, 2007), beliefs about victims (Pickett et al., 2013), and attitudes about the government's responsibility to victims may be more important to study than actual victimization.

Finally, although race was treated as a control variable in the current study, it is notable that African Americans were less likely to support mandatory sentences than individuals of other racial and ethnic backgrounds. Specifically, the odds of supporting mandatory sentences, controlling for other influences, was close to $60 \%$ lower among African Americans. This finding reminds us of the centrality of the White racial frame in understanding support for policies like mandatory sentences that contribute to systemic racism (Feagin, 2013). 
The idea that factual information—such as the efficacy of criminal justice institutions and experiences of crime—-may be interpreted through ideological and racial frames blurs the distinction between instrumental and expressive motives of punishment. As noted above, utilitarian and retributive goals can be pursued simultaneously (Hudson, 2001) and utilitarianism may be affectively satisfying (Carvalho and Chamberlen, 2017). In this study, we see evidence of both instrumental and expressive judgements about punishment influencing a preference for mandatory sentencing. The cross-sectional nature of the data and the limits of our measures prevent us from exploring whether the "emotional dog is wagging its rational tail," but a growing body of research from cognitive psychology provides strong evidence that moral reasoning is a post hoc explanation employed to persuade others about the correctness of intuitive moral judgements (Haidt, 2012). Thus, instrumental claims to crime control and expressive appeals to desert, harm, or fairness may be the result, not the cause, of intuitive judgements about punishment policy.

\section{Limitations}

Among the limitations of the current study is the lack of a measure capturing racial attitudes. Research has found that racial animus helps explain greater punitiveness among Whites (Frost, 2010; Hurwitz and Peffley, 2005; Pickett et al., 2014; Unnever and Cullen, 2010). Pickett et al. (2014) indicate racial animus operated as a mediator in the relationship between Tea Party Movement membership and support for punitive policies, indicating a connection between political affiliations, racial animus, and sentencing attitudes. Taking a somewhat different approach, Barker (2009) stresses how racial politics shape whether policies are punitive, and this impact varies by political context (also see Pfaff, 2017). 
To evaluate the robustness of the findings, we conducted a post-hoc analysis of the full model among the sample of racial and ethnic minorities $(n=246)$. The results were mostly unchanged. Minorities who thought prosecutors were doing a good job, that prisons protect, and that prisons punish were more likely to support mandatory sentences. Confidence in judges was no longer statistically significant $(p=.14)$, but the direction of the relationship and the effect size remained the same suggesting that differences in sample size account for the different results. Finally, political beliefs were unrelated to support for mandatory sentences among racial and ethnic minorities. This exploratory analysis adds confidence to the generalizability of the findings, but also point to the complex role that race, politics, and racial beliefs may play in explaining punitive beliefs.

As noted above, the measure of political participation used in the current study was limited to a single item question about voting behavior. More research is needed to better understand how various types of political participation and civic engagement affect tolerance, punitiveness, and confidence in criminal justice institutions. Although we did not find an association between punitiveness and political efficacy or political participation, scholars may benefit from exploring these concepts further. Lukensmeyer and Torres (2006) observe, for example, “Government officials often endorse public engagement because they believe it fosters active citizenship and has positive benefits to the substance, transparency, legitimacy, and fairness of policy development as well as a general view of government held by citizens” (p. 5). Trust in government, tolerance, and empathy for others that often result from public engagement (Nabatchi and Amsler, 2014) may shape participants' attitudes on public policy in this area. More empirical work is needed to test the paths between these concepts and more fully develop the measurement theory of public engagement. 
The ability to generalize from the results to other states is also unknown, particularly given the high level of direct voter engagement in the state surrounding mandatory sentencing. Scholars have also argued for the importance of state-level analysis of political structures and cultures in shaping punitive policy choices (Baker, 2006; Tonry, 2004), which argues against generalizing specific attitudes to other states. Nevertheless, this study adds to the evidence that punitive policy is shaped in part by instrumental concerns about crime and confidence in government institutions. Can the polls be trusted?

In 2016, opinion polls failed spectacularly to predict the "Brexit" vote in the United Kingdom or the outcome of the United States presidential election, in which Donald Trump defeated Hillary Clinton, who was predicted to win by comfortable margins. Recent election results were a sober reminder of the limitations of even the best polling methods and should prompt caution about drawing behavioral inferences from surveys of attitudes, intentions, and opinions. Although public attitudes are worthy of study and theorizing independent of their direct relationship to policymaking, most criminal justice scholars are also interested in the relationship between public attitudes and public policy.

Shortly after the data used in this research were collected in the summer of 2010, Oregon voters passed Measure 73, enacting a 90-day mandatory minimum sentence for a third drunk driving conviction and raising the minimum sentence for those convicted of more than one serious sexual offense to 25 years (Oregon Secretary of State, 2016). Measure 73 was sponsored by Crime Victims United, which appealed to voters' animosity toward sex offenders and sensitivity to local taxes (the measure also required the state to foot the bill for incarcerating DUI offenders) to generate support for the measure. The measure passed with 57\% of the vote (Oregon Secretary 
of State, 2016), which is 20 percentage points higher than the level of support for mandatory sentences found in this study.

The divergence we observe between voting behaviour and survey data is not a surprise to careful readers of the research. For example, Cullen et al. (2000) argue that attitudes about punishment are "mushy," not firm. Changes in contextual information, references to offender type, question wording, and even response choice order (Pickett and Baker, 2014) can result in substantial variation in levels of support for criminal justice policies. Consistent with assertions from the research literature, the passage of Measure 73 shows the complexity of public opinion on sentencing policy and continuing popular appeal of long prison sentences in the US. Along with the findings presented here, research demonstrates that the discipline would benefit from additional empirical knowledge that more directly studies how public interests, beliefs, and experiences contribute to criminal justice policy making. Even in a national context of declining punitiveness, mandatory sentences continue to appeal to residents in a progressive state as an effective means for protecting the public and punishing offenders.

The intuition that prisons and prosecutors keep people safe, but judges protect the rights of the accused, are powerful influences on judgements about how society should respond to the threat of crime. If judgements about punishment policy are indeed intuitive, does this mean that reasoned arguments and evidence about the efficacy and fairness of policies similar to mandatory sentences are bound to fall short? According to the social intuitionist model, moral persuasion is possible when we can get others to see issues in new ways that trigger different senses about what is right and wrong (Haidt, 2012). Reformers might need a more powerful metaphor to convey the value of alternatives to long, mandatory sentences and a more compelling story about 
the harms of prison to realize significant changes in punishment policy and establish a new common sense about how to safeguard our communities. 


\section{References}

American Association of Public Opinion Research, The (2008) Standard definitions:

Final dispositions of case codes and outcome rates for surveys, $5^{\text {th }}$ edition.

Lenexa, KS: AAPOR.

American Civil Liberties Union of Oregon, The (2016) Roadblocks to reform: District attorneys, elections, and the criminal justice status quo. Available at: www.aclu-or.org

American National Election Studies, The (nd) The ANES guide to public opinion and electoral behavior. Ann Arbor, MI: University of Michigan, Center for Political Studies. Available at: www.electionstudies.org.

Baker E and Roberts JV (2013) Globalization and the new punitiveness. In: Pratt J, Brown D, Hallsworth S and Morrison W (eds) The new punitiveness. New York, NY: Routledge, pp. 121-138.

Ballotpedia (nd) Oregon mandatory minimum prison sentences, measure 61 (2008).

Available at: https://ballotpedia.org

Barker V (2006) The politics of punishing: Building a state governance theory of American imprisonment variation. Punishment and Society 8(1): 5-32.

Barker V (2007) The politics of pain: A political institutionalist analysis of crime victims’ moral protests. Law and Society Review 41(3): 619-664.

Barker V (2009) The politics of imprisonment: How the democratic process shapes the way America punishes offenders. New York, NY: Oxford University Press.

Beckett K and Sasson T (2000) The politics of injustice: Crime and punishment in America. Thousand Oaks, CA: Pine Forge Press.

Carson EA and Anderson E (2016) Prisoners in 2015. Washington, DC: Bureau of Justice Statistics. 
Craig SC, Niemi RG and Silver GE (1990) Political efficacy and trust: A report on the NES pilot study items. Political Behavior 12(3): 289-314.

Cullen FT, Fisher BS and Applegate BK (2000) Public opinion about punishment and corrections. Crime and Justice 27: 1-79.

Ekins E (2014) 77\% of Americans favor eliminating mandatory minimum prison sentences for nonviolent offenders; 73\% favor restoring voting rights. Available at: http://reason.com/poll/2014/10/21/poll-77-of-americans-favor-eliminating-m

Enns PK (2014) The public's increasing punitiveness and its influence on mass incarceration in the United States. American Journal of Political Science 58(4): 857-872.

Epstein E (2017, March 14) Ignore the deniers: The murder rate is up significantly. The Weekly Standard. Available at: www.weeklystandard.com

Feagin JR (2013) The white racial frame: Centuries of racial framing and counterframing. Chicago, IL: Routledge.

Federal Bureau of Investigation (2015) Uniform crime reports: Crime in the United States. Washington, DC: Author. Retrieved from https://www.fbi.gov/aboutus/cjis/ucr/ucr-publications.

Feeley MM (1973) Two models of the criminal justice system: An organizational perspective. Law and Society Review 7(3): 407-425.

Flanagan TJ, Brennan PG and Cohen D (1991. Crime control ideology and policy positions in a state legislature (revisited). Criminal Justice Policy Review 5(3): 183-206.

Flanagan TJ, and Longmire DR (Eds.) (1996) Americans view crime and justice: A national public opinion survey. Thousand Oaks, CA: Sage.

Freiberg A and Gelb K (2008) Penal populism, sentencing councils, and sentencing 
policy. In: Freiberg A and Gelb K(eds) Penal populism, sentencing councils, and sentencing policy. Annandale, VA: Hawkins Press, pp. 1-14.

Frost NA (2010) Beyond public opinion polls: Punitive public sentiment and criminal justice policy. Sociology Compass 4(3):156-168.

Garland D (2001) The culture of control: Crime and social order in a contemporary society. Chicago, IL: University of Chicago Press.

Gaubatz KT (1995) Crime in the public mind. Ann Arbor, MI: The University of Michigan Press.

Gendreau P, Goggin C and Cullen FT (1999) The effects of prison sentences on recidivism. Ottawa, ON: Solicitor General Canada.

Gerber J and Engelhardt-Greer S (1996) Just and painful: Attitudes toward sentencing criminals. In: Flanagan TJ and Longmire DR (eds) Americans view crime and justice: A national public opinion survey Thousand Oaks, CA: Sage Publications, Inc., pp. 62-74.

Green DA (2009) Feeding wolves: Punitiveness and culture. European Journal of Criminology 6(6): 517-536.

Gray V and Hanson RL (eds) (2004) Politics in the American states: A comparative analysis (8th ed). Washington, DC: CQ Press.

Haidt J (2012) The righteous mind: Why good people are divided by politics and religion. Vintage.

Hudson B (2001) Punishments, rights, and difference: Defending justice in the risk society. In: Stenson K and Sullivan RR (eds) Crime, risk, and justice: The politics of crime control in liberal democracies. Portland, OR: Willan Publishing, pp. 143-172.

Hulse C (2016, September 16) Why the senate couldn't pass a crime bill both parties 
supported. The New York Times. Available at: www.nytimes.com

Hurwitz J and Peffley M (2005) Playing the race card in the post-Willie Horton era:

The impact of racialized code words on support for punitive crime policy.

Public Opinion Quarterly, 69(1): 99-112.

Hutton N (2005) Beyond populist punitiveness? Punishment and Society 7(3): 243-258.

Jaquiss N (2013, March 12) The hard truth about Oregon prisons: They work.

Williamette Weekly. Available at: http://www.wweek.com

Keeter S, Hatley N, Kennedy C and Lau, A (2017) What low response rates mean for telephone surveys. Pew Research Center. Available at: www.pewresearch.org

Lukensmeyer CJ and Torres LH (2006) Public deliberation: A manager’s guide to citizen engagement. IBM Center for the Business of Government. Available at: http://unpan1.un.org/

Merritt N, Fain T and Turner S (2006) Oregon's get tough sentencing reform: A lesson in justice system adaptation. Criminology and Public Policy 5(1): 5-36.

Nabatchi T and Amsler LB (2014) Direct public engagement in local government. The American Review of Public Administration 44(4_suppl): 63S-88S.

Nicholson-Crotty S, Peterson DA and Ramirez MD (2009) Dynamic representation (s): Federal criminal justice policy and an alternative dimension of public mood. Political Behavior 31(4): 629-655.

Oregon Secretary of State (2016) Initiative, referendum, and recall: 2006-2010. Oregon Blue Book. Available at: http://www.bluebook.state.or.us

Pfaff JF (2017) Locked in: The true causes of mass incarceration and how to achieve real reform. New York: Basic Books.

Peter D Hart Research Associates, Inc (2002) Changing public attitudes toward the criminal justice system: Summary of findings. Available at: 
http://www.prisonpolicy.org scans/CJI-Poll.pdf

Pew Charitable Trusts (2012) Public opinion on sentencing and corrections policy in America. Available at: http://www.pewtrusts.org

Pew Charitable Trusts (2016) The punishment rate: New metric evaluates prison use relative to reported crime. Available at:: http://www.pewtrusts.org

Peytchev A (2013) Consequences of survey nonresponse. The ANNALS of the American Academy of Political and Social Science 645: 88-111.

Pickett JT (2016) Reintegrative populism? Criminology and Public Policy 15(1): 131135.

Pickett JT and Baker T (2014) The pragmatic American: Empirical reality or methodological artifact? Criminology 52(2): 195-222.

Pickett JT, Mancini C and Mears DP (2013) Vulnerable victims, monstrous offenders, and unmanageable risk: Explaining public opinion on the social control of sex crime. Criminology 51(3): 729-759.

Pickett JT, Tope D and Bellandi R (2014) “Taking back our country”: Tea Party membership and support for punitive crime control policies. Sociological Inquiry 84(2): 167-190.

Princeton Survey Research Associates International (2006) The NCSC sentencing attitudes survey: A report on the findings. Available at: www.ncsc.org

Roberts JV (2003) Public opinion and mandatory sentencing: A review of international findings. Criminal Justice and Behavior 30(4): 483-508.

Roberts JV (2007) Public confidence in criminal justice in Canada: A comparative and contextual analysis. Canadian Journal of Criminology and Criminal Justice 49(2): 153-184.

Roberts JV, Crutcher N and Verbrugge P (2007) Public attitudes to sentencing in 
Canada: Exploring recent findings. Canadian Journal of Criminology and Criminal Justice 49(1): 75-107.

Roberts JV and Hough M (2005) Understanding public attitudes to criminal justice.

New York, NY: Open University Press.

Roberts JV, Stalans LJ, Indermaur D and Hough, M (2003) Penal populism and public opinion: Lessons from five countries. New York, NY: Oxford University Press. Simon J (2007) Governing through crime: How the War on Crime transformed American democracy and created a culture of fear. New York, NY: Oxford University Press.

Sundt J, Cullen FT, Thielo AJ and Jonson CL (2015) Public willingness to downsize prisons: Implications from Oregon. Victims and Offenders 10(4): 365-378.

Thielo AJ, Cullen FT, Cohen DM and Chouhy C (2016) Rehabilitation in a red state. Criminology and Public Policy 15(1): 137-170.

Teorell J (2006) Political participation and three theories of democracy: A research inventory and agenda. European Journal of Political Research 45(5): 787-810. Tonry M (2004) Thinking about crime. New York, NY: Oxford University Press.

Travis J, Western B and Redburn FS (2014) The growth of incarceration in the United States: Exploring causes and consequences. Washington, D.C.: The National Academies Press.

Unnever JD and Cullen FT (2010) The social sources of Americans’ punitiveness: A test of three competing models. Criminology 48(1): 99-129

Useem B, Liedka RV and Piehl AM (2003) Popular support for the prison build-up. Punishment and Society 5(1): 5-32.

Zarafonitou C (2011) Punitiveness, fear of crime, and social views. Punitivity: International Developments 8(2): 269-294. 
Zimring FE, Hawkins G and Kamin S (2001) Punishment and democracy: Three strikes and you're out in California. New York, NY: Oxford University Press. Zimring FE and Johnson DT (2006) Public opinion and governance of punishment in democratic political systems. The Annals of the American Academy of Political and Social Science 605(1): 266-280. 


\section{Footnotes}

${ }^{1}$ At the time that the survey was in the field, the political campaign for and against ballot Measure 73, which is increased mandatory minimums for sex offenders and drunk drivers, was active.

${ }^{2}$ The finding that global and specific attitudes about government exert different influences on attitudes about sentencing is an interesting parallel to the well-established finding that global and specific attitudes about punishment are distinct, but related, dimensions of belief (Cullen et al., 2000). 
Table 1. Level of Support for Mandatory Sentencing and Confidence in Judges and Prosecutors.

In general, do you think mandatory sentences are a good idea, or do you think that judges should have more say in deciding sentences?

Judges should have more say

$63.5 \%$

Mandatory sentences are good idea

$36.5 \%$

I'd like your opinion on how well different groups in Oregon are doing addressing crime and public safety.

\begin{tabular}{lcc}
\hline & Judges & $\begin{array}{c}\text { Prosecutors and } \\
\text { District Attorneys }\end{array}$ \\
\cline { 2 - 3 } Excellent job & $4.7 \%$ & $4.0 \%$ \\
Good job & $45.8 \%$ & $45.7 \%$ \\
Fair job & $37.0 \%$ & $39.1 \%$ \\
Poor job & $12.5 \%$ & $11.2 \%$ \\
\hline
\end{tabular}

Note: margin of error \pm 2.47 percentage points 
Table 2. Sources of Support for Mandatory Sentences $(n=1,142)$

\begin{tabular}{lccccccccc}
\hline & \multicolumn{3}{c}{ Model 1 } & \multicolumn{3}{c}{ Model 2 } & \multicolumn{3}{c}{ Full Model } \\
\cline { 2 - 10 } & B & SE B & $e^{B}$ & B & SE B & $e^{B}$ & B & SE B & $e^{B}$ \\
\hline Prosecutor Efficacy & $.32^{*}$ & .11 & 1.37 & & & & $.32^{*}$ & .12 & 1.37 \\
Judicial Efficacy & $-.25^{*}$ & .11 & .777 & & & & $-.25^{*}$ & .12 & .78 \\
Prison Protects & $.93^{*}$ & .15 & 2.52 & & & & $.78^{*}$ & .16 & 2.18 \\
Prison Punishes & $.79 *$ & .11 & 1.13 & & & & $.61 *$ & .29 & 1.84 \\
Political Trust & & & & -.01 & .03 & .984 & .02 & .04 & 1.02 \\
Political Efficacy & & & & .01 & .14 & 1.01 & -.02 & .16 & .981 \\
Conservative & & & & $.23^{*}$ & .05 & 1.26 & $.21 *$ & .05 & 1.23 \\
Political Participation & & & & .10 & .25 & 1.09 & .02 & .27 & 1.02 \\
Fear of Crime & .13 & .11 & 1.13 & .18 & .10 & 1.20 & .12 & .11 & 1.13 \\
Victimization & .09 & .08 & 1.09 & .06 & .08 & 1.06 & .10 & .09 & 1.10 \\
Perceived Risk & $.30^{*}$ & .15 & 1.34 & $.29 *$ & .15 & 1.34 & .22 & .16 & 1.25 \\
African American & $-.68 *$ & .25 & .509 & $-1.0 *$ & .24 & .355 & $-.90 *$ & .28 & .409 \\
Age & .01 & .01 & 1.00 & .01 & .005 & 1.00 & .01 & .01 & 1.00 \\
Female & -.29 & .15 & .747 & -.25 & .145 & .777 & -.34 & .16 & .714 \\
Income & $.10^{*}$ & .04 & 1.11 & $.10^{*}$ & .040 & 1.10 & $.09 *$ & .04 & 1.09 \\
\hline$\chi^{2}$ & & $93.91^{*}$ & & & $77.72^{*}$ & & & $106.81 *$ \\
$d f$ & & 11 & & & 11 & & & 15 & \\
\hline
\end{tabular}

